\title{
Auditor Choice: After Enron
}

H. Francis Bush, (Email: bushhf@vmi.edu), Virginia Military Institute

\begin{abstract}
In this study, the author examines the choice of auditor for firms who had contracted with Arthur Andersen prior to its collapse in the aftermath of Enron. This study was motivated by previous research on factors affecting the choice, including but not limited to size, geography, industry and financial condition. The results, in general, indicate that the choice among the Big Four accounting firms is not affected by these variables. This opens two possibilities: either that the choice is based on less tangible factors or such factors are overwhelmed by the size of the Big Fours accounting firms. However, when considered together, multivariate discriminant analysis (MDA) develops a model that is able to predict which firm will be chosen at a significantly higher than simply guessing among the Big Four CPA firms. This result is driven by the results of two of the four firms.
\end{abstract}

\section{INTRODUCTION}

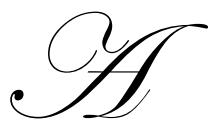

uditing services represent a contract between the firm (the client) and the auditor where both parties agree to an exchange of services for a fee. The contract represents a mutual agreement where the clients and auditors' characteristics are well matched given the auditing environment. A client will only change auditors when there is a significant change in the composition of the either the client's own characteristics, such as a merger, the auditor's characteristics, such as an addition of non-auditing services, or the auditing environment, such as technology changes because the costs to the client are significant (Beattie and Fearnley, 1995). Such a significant change in the auditing environment began in 2001 with the collapse of Enron and continues today with the regulations of the Sarbanes-Oxley Act of 2002.

As these proceedings against Arthur Andersen and key principals were making their way through the courts and the media, various events began to unfold - Corporations began to dismiss Andersen as their auditor, and the Sarbanes-Oxley Act of 2002 was introduced and passed in the Congress of the United States. Among the various issues that this act examined was auditors' independence. Specifically, should there be mandatory rotation of auditors?

Significant literature exists that examines the choice of auditor using cross sectional data over an extended period of time. These studies have focused on external variables of the client firms, such as Schwartz and Soo (1996), and Frankel et al. (1995), the size of the auditing firm, such as Johnson and Lys (1990) and Dopuch and Simunic (1980), and the concerns of the decision makers, such as Beattie and Fearnley (1998) as variables that influence the choice of auditors. This study reviews various aspects of Fortune 500 firms who had contracted with Andersen for two years prior to its demise. This study uses cross-sectional data but from a relatively short period of economic time. Further, issues surrounding Big Four (Formerly Five) firms are not present because all the choices that were studied involved switching from Andersen to one of the remaining Big Four. The results suggests that the choice among the Big Four accounting firms is not affected by the client's profitability, cash flow, financing, degree of complexity, industry, and audit fees, but perhaps intangible factors such as the realignment of the auditing workforce

The remainder of this paper is organized as follows. In Section 2, I summarize the arguments and present the hypotheses. I present the data and methodology in Section 3. In Section 4, I discuss the empirical results, and in Section 5, I summarize my conclusions, and suggestions for future investigation. 


\section{DEVELOPMENT OF THE HYPOTHESES}

As the investigation of the collapse of Enron played out in the media, firms began the painful process of considering selecting an alternative auditor for future services. On March 7, 2002, Arthur Andersen was indicated for obstruction of justice as a result of the actions of its principals in response to investigations concerning the collapse of Enron. The subsequent conviction of this felony halted the operations of the firm permanently. Consequently, all of Andersen's clients would select a new auditor.

These unfortunate events provide an excellent opportunity to reconsider the factors determining auditor choice that have been discussed previously in the literature. As one of the Big Five, Andersen had many clients who would now be selecting new auditors. Although the decision to switch auditors may have been developing as the events unfolded, there was a short period of time between the collapse of Enron to the closing of Andersen' doors. This meant the researcher could focus on cross sectional data, and did not need to consider the effects associated with the changes in the category of auditors.

Past research has identified several variables that determine or influence auditor choice selection process. Johnson and Lys (1990) argued "that that economic considerations affect client-auditor alignments: individual audit firms obtain competitive advantages through specialization, and purchase audit services from the least costly supplier." (p. 281.) They selected approximately 600 auditor changes from 1973 to 1982 . They investigated four broad factors of characteristics that influence the contracting between client and auditors - expansion, financing, profitability, and audit risk. Expansion referred to changes associated with the size of the audit firm. Discussion on expansion included growth in assets, geographical dispersion and complexity of the client. Discussion on financing focused on new debt and equity issues. Profitability was measured in terms of both average return on assets and average operating cash to assets. Audit risk was investigated through client size, leverage, times-interest-earned, qualifications and auditor disagreements. Based on both the Spearman (rank-order) correlation coefficient and Mann-Whitney test, the authors reported the following variables to be significantly correlated with audit firm size: Asset growth (before), Asset growth (after), new acquisitions (before), new acquisitions (after), Return on Assets (before), Leverage before, Times-interest-earned (after) and Auditor disagreement. Subsequent to the univariate analysis, the authors regressed audit firm size the dependent variable on a subset of variables. Specifically, they found that compound asset growth rates before the switch, the change in external financing, cash flow performance and times-interest-earned were significant. Acquisitions and compound asset growth rates after were not significant at traditional levels.

Additional variables affecting auditor choice were investigated. Schwartz and Soo (1996) applied multivariate techniques to study the effects of a client's size as measured by the natural log of total assets, negative disclosures, the existence of a going concern opinion, the amount of new securities to be issued, and the time from reporting the change in auditors to the first fiscal year-end that the new audit for the new auditor reports on the filing the 8-k form with the SEC. The sample was based on firms that had filed form 8-K for changing auditors from 1988 - 1993. They reported that size was significant for both compliance with the SEC timing requirements and the amount time for the filing. The coefficient was negative, as the size of the of the new audit firm increased, the amount time between the switch and filing the 8-K decreased. Further, the existence of a going concern opinion, issuing new securities, and issuing new securities were significant in predicting compliance, and the time from reporting the change in auditors to the first fiscal year-end was significant in predicting the time for filing.

Myers, et al (2003) examined the effects of auditor tenure, age of the firm, industry growth, cash flow, auditor type (Big N Auditor or not) and industry (based on the two-digit SIC code) on a firm's earning quality as measured by accruals. Using data from 1988 - 1999, they found that each variable was significant except industry growth, when absolute measures were used with both discretionary accruals and current accruals

Beattie and Fearnley (1998) interviewed key decision makers of the factors that affected the auditor choice. Their study focused on the choice of twelve firms in the United Kingdom that "conducted a competitive tender, changed auditors, or both between 1989 and 1992." (p. 77.) Their study differed in various aspects from previous investigations. Data was gathered and interpreted from a small number of interviews over a relatively short period 
of time. They did not report statistically significant effects but rather summarized the factors mentioned by the decision makers. Of particular interest, they noted that: (1) Important factors included personal contacts to find reputable auditors, the availability of services other than auditing, the need to provide "overseas support," geographical proximity, fees if they exceeded acceptable limits, (2) None of the companies suggested that industry specialization was a consideration.

This study is about auditor switching in a relatively short period of time, from one Big $\mathrm{N}$ firm to another, when the auditing environment was dominated by the collapse of Enron and the demise of one the Big N firms. Consequently, I investigated the effects of the following variables. Johnson and Lys (1990) reported that return on assets before switching and changes in external financing were significant while acquisitions and compound asset growth rates were not. Schwartz and Soo (1996) also reported significant effects from issuing new securities. Finally, Beattie and Fearnley's (1998) interviews revealed a role for "overseas support" and indicated conflicting results on the importance of industry. Further, they commented that there was a conflict over the existence of any concern for auditors' fees. Myer et al (2003) indicated that cash flows and industry as determined by the two-digit SIC code were significant in determining discretionary and current accruals. Table 1 summarizes the variable, and how it is measured.

Table 1

Independent Variables and Equations

\begin{tabular}{|l|c|}
\hline Profitability & $\frac{\text { Operating Income }}{\text { Total Assets }}$ \\
\hline Cash Flow & $\frac{\text { Cash Flows from Operations }}{\text { Total Assets }}$ \\
\hline Financing & $\frac{\text { Long-term Debt Maturing in five years }}{\text { Total Long-term Debt }}$ \\
\hline Complexity & Number of Reportable Segments + Geographical Segments \\
\hline Industry & Two-Digit SIC Industry Code \\
\hline Audit Fees & $\frac{\text { Total Fees Reported to the SEC }}{1,000,000}$ \\
\hline
\end{tabular}

Total liabilities were also used as the divisor without any difference it the results.

Fees reported for only auditing services were also used without any difference it the results.

Two variables, financing and complexity, were measured in a different manner than in previous research. Financing looked strictly at the amount of long-term debt that would need to be re-financed in the upcoming five years as opposed to actual equities issued after the switch. This adjustment was made because the future issues would not be all available at this point. Complexity was measured as the sum of the number of operating and geographic segments reported in the financial statements. All firms filing with the SEC must indicate the amount of long-term debt maturing in the next five years. Thus, the need for financing in the near future could be estimated as the percentage of long-term debt that would be replaced in the next five years. Complexity is reported in both the number of reportable segments and geographical regions. Consequently, the sum was used as a measure of can be measured in the effects of both simultaneously. Lastly, auditing fees were divided by 1,00,000 to make them comparable to the size of the other variables.

\section{DATA AND METHODOLOGY}

A widely accepted classification of large firms in the U.S. is based on Fortune Magazine. Consequently, firms for this study were selected from the Fortune 500. Initially, it was hoped that all firms would be included. However, several firms were excluded because they were involved in mergers, bankruptcy, or data was not available in the SEC's Edgar database. The existence of a merger or bankruptcy would impact the choice of auditor. The resulting sample was composed of 85 firms that had contracted with Andersen for the years 2000 and 2001. At the time of the study, one firm that contracted with Andersen and five firms that had not contracted with Andersen did not have their proxy statements available on Edgar. 
Using the firms listed by Namelst.com as the Fortune 500, data was collected identifying each firm's auditor for the years 2000, 2001, and 2002 and the auditors' fees for 2001 and 2002. The data was collected from the firms' websites, and from the Annual Report (10-K) and Other Definitive Proxy Statement (DEF 14A) available on Edgar.

Each variable would be investigated using univariate techniques as well investigated the set of variables using multivariate techniques. For each factor, the following ANOVA model using the Big Four CPA firm as a dependent variable was tested.

CPA Firm $=\mathrm{f}$ (Profitability, Cash Flow, Financing, Complexity, Industry, Total Fees)

MDA would be used to investigate all the variables simultaneously.

\section{EMPIRICAL RESULTS}

Table 2 presents the descriptive statistics for each variable for each firm and the total. Each firm was assigned a number strictly for reporting purposes. First, for each accounting firm, the mean score on each variable is presented followed by the sample variance in parentheses. Second, the final column provides the mean and sample variance for each variable for the total sample. A review of the means show that only three variables appear to deviate from the group. Specifically, the profitability ratio and financing for Firm 3, and cash flow for Firm 4

Table 2

Summary Statistics

\begin{tabular}{|l|c|c|c|c|c|}
\hline $\begin{array}{l}\text { Sample Mean } \\
\text { Variance) }\end{array}$ & Firm 1 & Firm 2 & Firm 3 & Firm 4 & Total \\
\hline Profitability & .089781 & .096361 & .029609 & .070779 & .072284 \\
& $(.003798)$ & $(.005662)$ & $(.016543)$ & $(.020543)$ & $(.011145)$ \\
\hline Cash Flow & .102941 & .106656 & .124036 & .071244 & .1022227 \\
& $(.002237)$ & $(.003985)$ & $(.066524)$ & $(.004709)$ & $(.018646)$ \\
\hline Financing & .518112 & .528700 & .859115 & .476058 & .595702 \\
& $(.173147)$ & $(.091532)$ & $(1.324953)$ & $(.070322)$ & $(.427257)$ \\
\hline Complexity & 4.75000 & 6.166667 & 6.142857 & 5.111111 & 5.470588 \\
& $(6.416667)$ & $(6.382353)$ & $(5.228571)$ & $(6.928105)$ & $(6.418768)$ \\
\hline Industry & 45.89286 & 43.94444 & 42.52381 & 42.666667 & 43.96471 \\
& $(316.8399)$ & $(394.9967)$ & $(328.5619)$ & $(278.1176)$ & $(318.4154)$ \\
\hline Total Fees & 6.278032 & 5.722514 & 6.962703 & 7.587161 & 6.606774 \\
& $(25.52614)$ & $(27.30650)$ & $(52.90931)$ & $(87.19727)$ & $(44.41688)$ \\
\hline
\end{tabular}

Table 3

Results of ANOVA for each variable

\begin{tabular}{|l|c|c|}
\hline & F - Statistic & p-value \\
\hline Profitability & 1.760072 & 0.161379 \\
\hline Cash Flow & 0.484933 & 0.693687 \\
\hline Financing & 1.502662 & 0.220106 \\
\hline Complexity & 1.878769 & 0.139711 \\
\hline Industry & 0.180922 & 0.909062 \\
\hline Total Fees & 0.270893 & 0.846214 \\
\hline
\end{tabular}

For each factor, the results of the test of the ANOVA model are presented in table 3.

No factor is significant at any traditional level. These findings are consistent with the preliminary discussion of Beattie and Fearnley (1998) in reference to complexity, industry and audit fees. It was only in the subsequent discussion of the interviews that Beattie and Fearnley indicated that fees were of interest. Their work 
however was a summary of remarks made in interviews without statistical analysis. However, their results conflicted the results reported by Johnson and Lys (1980) in reference to profitability, cash flow, and by Schwartz and Soo (1996) in reference to financing. These inconsistencies would perhaps be best explained by two differences in this study from the previous studies. My study was based on significant change in the audit environment as opposed to the choice of management and the choice was strictly from one of the Big CPA firms to one of the remaining Big Four CPA firms.

For comparative reason alone, a MDA was also performed. ${ }^{1}$ The results are presented in Table 4. Each row represents the actual auditing firm and the columns represents the firm selected by the MDA model. The number of each classification and the percent of total for the actual auditing firm are presented in each cell. The cells where the row and column match are correctly predicted switches. In general, the results lack statistical significance as were expected. However, it should be noticed that the percentage of correctly identified switches was noticeably higher for the second Big Four CPA firm.

Table 4

Classification Summary for Calibration Data Cross-validation Summary using 2 Nearest Neighbors

\begin{tabular}{|c|c|c|c|c|c|c|}
\hline \multicolumn{7}{|c|}{ Predicted Auditor $^{2}$} \\
\hline Actual Auditor & 1 & 2 & 3 & 4 & Other & Total \\
\hline 1 & $\begin{array}{c}5 \\
(17.86)\end{array}$ & $\begin{array}{c}7 \\
(25.00)\end{array}$ & $\begin{array}{c}9 \\
(32.14)\end{array}$ & $\begin{array}{c}4 \\
(14.29)\end{array}$ & $\begin{array}{c}3 \\
(10.71)\end{array}$ & $\begin{array}{c}28 \\
(100.00)\end{array}$ \\
\hline 2 & $\begin{array}{c}0 \\
(0.00)\end{array}$ & $\begin{array}{c}13 \\
(72.22)\end{array}$ & $\begin{array}{c}1 \\
(5.56)\end{array}$ & $\begin{array}{c}4 \\
(22.22)\end{array}$ & $\begin{array}{c}0 \\
(0.00)\end{array}$ & $\begin{array}{c}18 \\
(100.00)\end{array}$ \\
\hline 3 & $\begin{array}{c}4 \\
(19.05) \\
\end{array}$ & $\begin{array}{c}4 \\
(19.05) \\
\end{array}$ & $\begin{array}{c}5 \\
(23.81) \\
\end{array}$ & $\begin{array}{c}8 \\
(38.10) \\
\end{array}$ & $\begin{array}{c}0 \\
(0.00) \\
\end{array}$ & $\begin{array}{c}21 \\
(100.00) \\
\end{array}$ \\
\hline 4 & $\begin{array}{c}2 \\
(11.11)\end{array}$ & $\begin{array}{c}6 \\
(33.33) \\
\end{array}$ & $\begin{array}{c}3 \\
(16.67)\end{array}$ & $\begin{array}{c}7 \\
(38.89) \\
\end{array}$ & $\begin{array}{c}0 \\
(0.00)\end{array}$ & $\begin{array}{c}18 \\
(100.00) \\
\end{array}$ \\
\hline
\end{tabular}

The only result of interest is derived from the percentage of correctly identified switches. Random choice would anticipate correctly identifying 25 percent of the switches. The total number of correctly identified switches was 30 out of 85 (35.29 percent). When tested against the hypothesis of random choice the $\mathrm{z}$-statistic is 2.19 , which has a p-value of .0143. Thus, the MDA model predicted audit switches at a significantly higher rate than random choice. Further, for both Big Four CPA firms 2 and 4, the MDA model predicted these firms at a rate statistically higher than random choice. Firm 2 was correctly identified 13 out 18 switches, producing a significant z-statistic of 4.62 (p-value $\approx .0000)$ and Firm 4 was correctly identified 7 out of 18 switches, producing a $\mathrm{z}$-statistic of 1.36 (pvalue $=.0869)$. This evidence is consistent with the literature that indicates these factors are important to determine auditor choice.

\section{CONCLUSIONS}

The evidence suggests that at first look the factors, Profitability, Cash Flow, Financing, Complexity, Industry, and Total Fees are not significant factors in management's choice of a Big Four Auditor. However, a curious result was revealed when a MDA model was developed. This model was able to predict auditor choice at a level significantly higher than random guessing. There are several possible causes for these conflicting results. First, the choice was made from among only Big Four CPA firms. Second, the change in the auditing environment was sufficient to overwhelm the effects of the factors because the issues surrounding integrity and shifts in employment within the auditing profession dominated the industry at that time. Third, decision-making is a nonlinear multivariate process. Consequently, individual variable may be an inappropriate focus.

\footnotetext{
${ }^{1}$ Multiple regression models were also developed but did not indicate any significant results. The assumptions of regression techniques may not be robust for such classifications.

${ }^{2}$ Big Four auditing firms were assigned a number without any particular meaning.
} 
Given these results, further study would investigate various aspects of this study. Replications could expand the applicability of these findings to smaller firms, and to consider other variables that are outside the scope of this study, such as liquidity measures, length of time with Andersen, etc. Such replications would provide greater understanding of the auditor switching that has taken place in response to the collapse of Enron and Andersen and the Sarbanes-Oxley Act of 2002. In addition, those who actually participated in the change could be surveyed or interviewed similar to Beattie and Fearnley (1998)

The application of these results is limited by the nature of the sample. Even though the sample was composed of more than 80 percent of the firms from the Fortune 500 that switched auditors in 2002, the results are not necessarily relevant for smaller firms. Further, focusing on the years surrounding the collapse of Enron and Andersen may capture other variables for which controls were not applied. As mentioned above, these issues can be addressed in additional studies.

\section{BIBLIOGRAPHY}

1. $\quad 107^{\text {th }}$ US Congress. 2002. Sarbanes-Oxley Act of 2002, H.R. 3763. 116 Stat. 745.

2. Beattie, V., and S. Fearnley. 1998. "Auditor Changes and Tendering: UK Interview Evidence". Accounting, Auditing and Accountability Journal 11: 72-98.

3. Beattie, V., and S. Fearnley. 1995. "The Importance of Auditing Firm Characteristics and the Drivers of Auditor Change in UK Listed Companies". Accounting and Business Research 25: 227-239.

4. Dopuch, N. and King, R. R. 1992. "The impact of MAS on Auditors' Independence: An experimental market study". Journal of Accounting Research. 29 (supplement): 60-98.

5. Myers, J. N., Myers, L. A., and Omer, T. C. 2003. "Exploring the term of the auditor-client relationship and the quality of earnings: A case for mandatory auditor rotation?" The Accounting Review. 78 (July): 779-799.

6. Johnson, W. B., and T. Lys. 1990. "The market for audit services: Evidence from voluntary auditor changes". Journal of Accounting and Economics 12 (January): 281-308.

7. Pany, K. and Reckers, P. M. J. 1988. "Auditor performance of MAS: A study of its effects on decisions and perceptions". Accounting Horizons 2 (June): 31-38.

8. Schwartz, K. B., and B. S. Soo. 1996. "Evidence of Regulatory Noncompliance with SEC Disclosure Rules on Auditor Changes". The Accounting Review 71 (October): 555-572. 